\title{
Ghrelin attenuates the growth of HO-8910 ovarian cancer cells through the ERK pathway
}

\author{
R.X. Bai ${ }^{1}$, W.P. Wang ${ }^{2}$, P.W. Zhao ${ }^{3}$ and C.B. Li $^{4}$ \\ ${ }^{1}$ Department of Clinical Laboratory, Inner Mongolia People's Hospital, Hohhot, China \\ ${ }^{2}$ Graduate College, Inner Mongolia Medical University, Hohhot, China \\ ${ }^{3}$ Microbiology and Immunology Laboratory, School of Basic Medical Science, Inner Mongolia Medical University, Hohhot, China \\ ${ }^{4}$ School of Basic Medical Science, Inner Mongolia Medical University, Hohhot, China
}

\begin{abstract}
Ovarian cancer is one of the most common causes of death from gynecologic tumors and is an important public health issue. Ghrelin is a recently discovered bioactive peptide that acts as a natural endogenous ligand of the growth hormone secretagogue receptor (GHSR). Several studies have identified the protective effects of ghrelin on the mammalian reproductive system. However, little research has been done on the effects of ghrelin on ovarian cancer cells, and the underlying mechanisms of these effects. We sought to understand the potential involvement of mitogen-activated protein kinases (MAPKs) in ghrelin-mediated inhibition of growth of the ovarian line HO-8910. We applied different concentrations of ghrelin and an inhibitor of the ghrelin receptor (D-Lys3-GHRP-6) to HO-8910 cells and observed the growth rate of cells and changes in phosphorylation of the MAPKs ERK1/2, JNK and p38. We discovered that ghrelin-induced apoptosis of $\mathrm{HO}-8910$ cells was though phosphorylated ERK1/2, and that this phosphorylation (as well as p90 ${ }^{\text {rsk }}$ phosphorylation) was mediated by the GHSR. The ERK1/2 pathway is known to play an essential part in the ghrelin-mediated apoptosis of HO-8910 cells. Hence, our study suggests that ghrelin inhibits the growth of HO-8910 cells primarily through the GHSR/ERK pathway.
\end{abstract}

Key words: Ghrelin; MAPKs; HO-8910; Apoptosis

\section{Introduction}

Every year more than 225,000 women are diagnosed with ovarian cancer and an estimated 140,000 deaths are caused by ovarian cancer worldwide (1). Five-year survival for patients with ovarian cancer is $92 \%$ if the tumor is detected at an early, localized stage. However, early diagnosis is rare; $85 \%$ of ovarian cancers are detected at a more advanced stage because symptoms are easily missed until the disease has spread to other body regions (2). Thus, the overall five-year survival for all women diagnosed with epithelial ovarian carcinoma is only $44 \%$ $(2,3)$. Because of the overall high mortality of ovarian cancer, women at increased risk may be counseled to undergo prophylactic (and possibly unnecessary) oophorectomy (4).

Ghrelin is an endogenous ligand for the growth hormone secretagogue receptor (GHSR). It is a 28 -amino acid peptide produced from a pre-prohormone with a length of 117 amino acids. The mature form of ghrelin can undergo several posttranslational modifications, including addition of a fatty-acid chain (n-octanoic acid) to the serine 3 residue (5). Ghrelin has been shown to stimulate secretion of growth hormone, and to have orexigenic and adipogenic effects (6). Most ghrelin is produced in the stomach by a distinct group of endocrine cells located within the gastric oxyntic mucosa $(7,8)$, with smaller amounts produced by other organs. Small amounts of ghrelin have also been observed elsewhere in the gastrointestinal tract and pancreas, and its activity influences the metabolism of glucose and lipids.

This peptide also has less well-understood roles in other tissues and organs. Ghrelin expression has been reported at low levels in the brain, pituitary gland, kidneys, and thyroid gland, as well as in several areas of the reproductive system, including the placenta, testes, and ovaries (9). A recent report describes ghrelin expression at mRNA and peptide levels in the ovaries of adult rats. mRNA levels of ghrelin in rat ovaries were monitored throughout the estrous cycle to better understand physiologic regulation of expression of the ghrelin gene in ovaries (10). Despite persistent expression of the signal throughout all stages of the estrous cycle, mRNA levels of ghrelin change in a cyclic fashion, with lowest expression occurring in the proestrus phase, and maximum values in the diestrous phase (11).

Correspondence: P.W. Zhao: <pengwzhao@126.com> | C.B. Li<licunbao5159@sina.com>

R.X. Bai and W.P. Wang contributed equally to this article.

Received June 24, 2015 | Accepted November 16, 2015 
In many (though not all) normal tissues, ghrelin stimulates cell proliferation and protects against apoptosis (7). In contrast, there are numerous reports of ghrelin-mediated inhibition of the growth of cancer cells (9), including the ovarian cancer cells known as HO-8910 (2). There are conflicting reports describing positive and negative effects of ghrelin and other growth hormone-stimulating molecules on the growth of tumor cells in vitro $(12,13)$. The activity of several signaling pathways, including mitogen-activated protein kinase (MAPK) pathways, have been implicated in these processes. We investigated if ghrelin exerts its inhibitory effects on HO-8910 cells through GHSR activation and the downstream activity of MAPKs.

\section{Material and Methods}

Unless specified otherwise, all chemicals and reagents were purchased from Sigma-Aldrich (USA). Antibodies against IgG, glyceraldehyde-3-phosphate dehydrogenase (GAPDH), ERK1/2, JNK, p90rsk, phospho-ERK1/2, phosphoJNK and phospho-p90rsk1 (Ser380) were purchased from Millipore (USA). Unless specified otherwise, culture of the ovarian line HO-8910 (Chinese Academy of Sciences, China) took place at $38.5^{\circ} \mathrm{C}$ with $5 \% \quad \mathrm{CO}_{2}$ under humidified air. The HO-8910 cell line is derived from a 51-year-old Chinese patient with ovarian cancer and ascites in 1994.

\section{RNA extraction and reverse-transcription-polymerase} chain reaction (RT-PCR)

Total RNA was isolated from $\mathrm{HO}-8910$ cells using an RNeasy kit (Qiagen, Germany). RNA samples were treated with RNase-free DNase I to remove contamination of genomic DNA. RNA content of samples was too low to be quantified accurately by spectrometry. Thus, $6.5-\mu \mathrm{L}$ RNA aliquots were converted to cDNA by reverse transcription, then amplified (Takara Bio, Japan). PCR primers for the ghrelin receptor were: sense, $5^{\prime}$-TCTT CCTTCCTGTCTTCTGTC-3'; antisense, 5'-AGTCTGAA CACTGCCACC-3' (14).

\section{3-(4,5-dimethylthiazol-2-yl)-2,5-diphenyltetrazolium bromide (MTT) assay}

Initially, cells were grown in 96-well plates $\left(1 \times 10^{3}\right.$ cells/ well) with ghrelin and D-Lys3-GHRP-6. Control cells were switched from RPMI1640 to Dulbecco's modified Eagle's medium (DMEM) containing $0.1 \%$ dimethyl sulfoxide (DMSO). At 12, 24, 36, 48, 60 and $72 \mathrm{~h}$ after treatment with ghrelin and D-Lys3-GHRP-6, $20 \mu \mathrm{L}$ of MTT was added to each well to a final concentration of $0.5 \%$. After $4 \mathrm{~h}$ incubation at $37^{\circ} \mathrm{C}$ in the dark, $150 \mu \mathrm{L}$ DMSO was added to each well for $10 \mathrm{~min}$ to dissolve formazan crystals. Absorbance was measured using a microplate reader (ELx800; BioTek, USA) at $490 \mathrm{~nm}$. Experiments were repeated three times. Viability of ghrelin- and D-Lys3-GHRP-6-treated cells was expressed as the percentage of population growth plus standard error of the mean relative to that of untreated control cells. Cell death caused by ghrelin and D-Lys3-GHRP-6 was calculated as a percentage of inhibition using the following formula: Percent inhibition $=(1-$ mean experimental absorbance/mean control absorbance) $\times 100$.

\section{Assay to determine effective concentrations of ghrelin} and D-Lys3-GHRP-6 (ghrelin receptor inhibitor)

Ghrelin was added to HO-8910 growth media to final concentrations of $121,152,182,212$, and $242 \mathrm{nM}$, cells were cultured for $12,24,36,48,60$ and $72 \mathrm{~h}$, and then the growth of HO-8910 cells was analyzed. Once the optimum ghrelin concentration and treatment duration to achieve inhibition were determined, this treatment was repeated with addition of D-Lys3-GHRP-6 to final concentrations of $10^{-8}, 10^{-9}, 10^{-10}$, and $10^{-11} \mathrm{mg} / \mathrm{mL}$. HO-8910 cells were then cultured for $12,24,36,48,60$ and $72 \mathrm{~h}$, and their growth analyzed.

\section{Western blotting}

$\mathrm{HO}-8910$ cells were homogenized and proteins separated by electrophoresis on $8-12 \%$ sodium dodecyl sulfate/polyacrylamide gels, and then transferred to immunoblot nitrocellulose membranes. Membranes were blocked for $30 \mathrm{~min}$ at room temperature with phosphatebuffered saline (PBS) containing $5 \%$ fat-free milk and $0.1 \%$ Tween 20 . Then, membranes were incubated with primary anti-Rac1 antibody for $\geqslant 1 \mathrm{~h}$ at room temperature, or overnight at $4^{\circ} \mathrm{C}$. Then, membranes were washed thrice

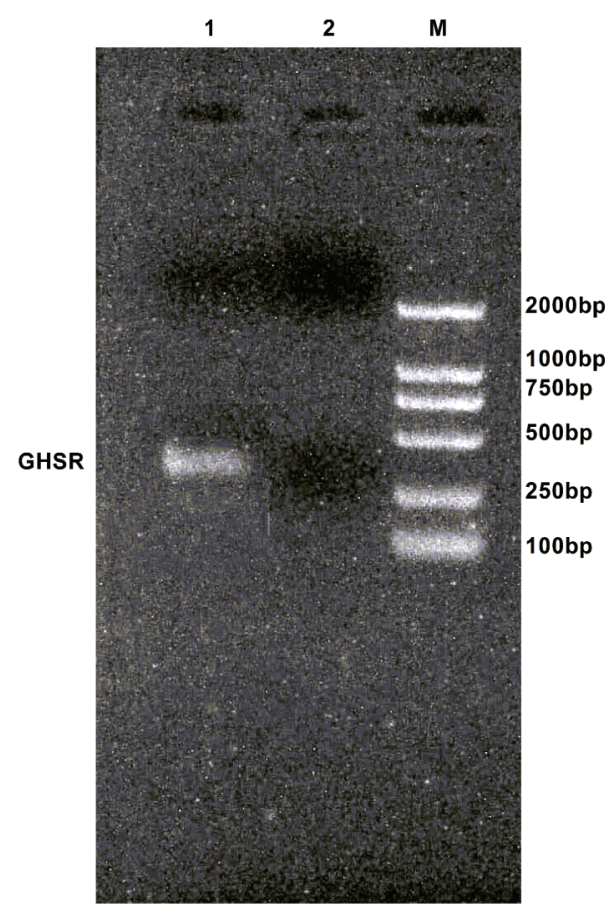

Figure 1. Expression of GHSR mRNA in HO-8910 cells by RT-PCR. 1: sample; 2: water blank; M: DNA Marker DL 2000. 
with PBS containing $0.1 \%$ Tween 20 , incubated with peroxidase-conjugated secondary antibodies, and developed using ECL reagent (Pierce, USA).

\section{siRNA design}

RNA interference was used to silence expression of ERK1/2 in HO-8910 cells. ERK1/2-siRNA (TGAATTGTATCATCAACAT) was synthesized by Gene Pharma Biotechnology (China).

\section{Transfection of siRNA}

siRNA transfection was conducted using lipofectamine according to the protocol supplied by Invitrogen (USA). Briefly, $1 \times 10^{5}$ cells were seeded onto six-well plates containing antibiotic-free medium and incubated overnight. For each well, $5 \mu \mathrm{L}$ siRNA was mixed with $125 \mu \mathrm{L}$ Opti-MEM I. The mixture was combined with a solution of $5 \mu \mathrm{L}$ lipofectamine in $125 \mu \mathrm{L}$ Opti-MEM I. After $20 \mathrm{~min}$ at room temperature, the mixture was applied to cells in an appropriate volume of OptiMEM I to achieve a final concentration of $100 \mathrm{nM}$ for each
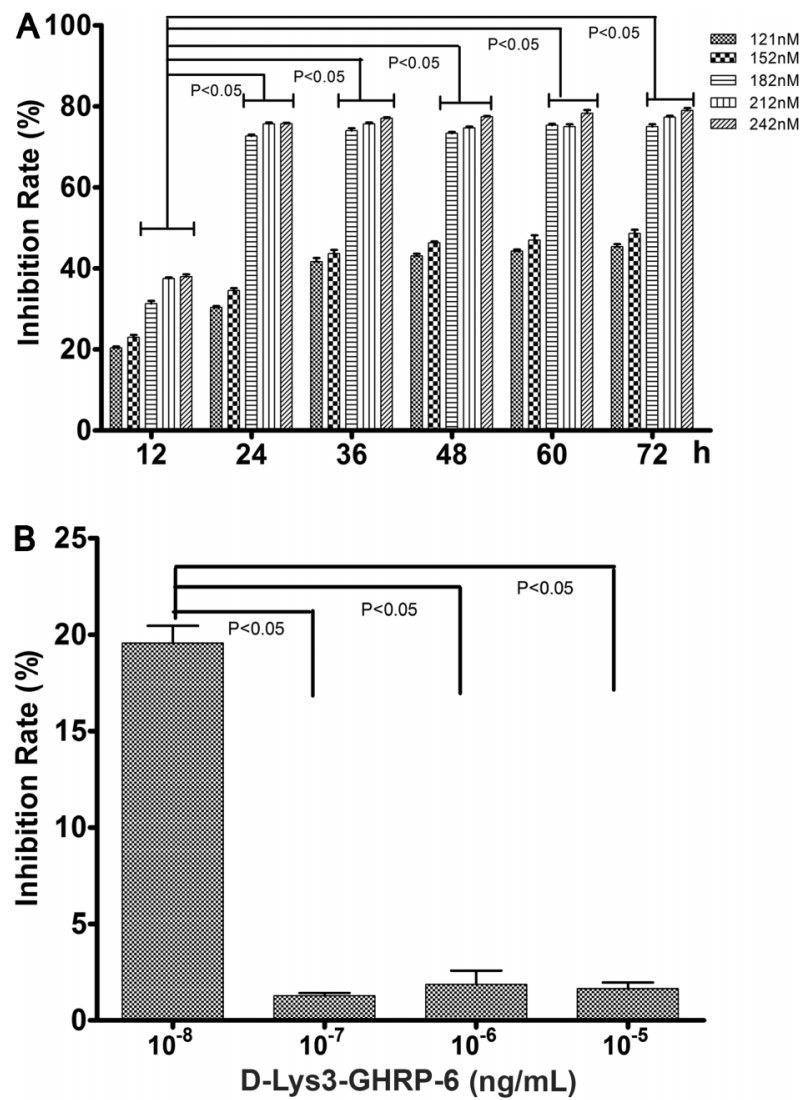

Figure 2. Growth of HO-8910 cells after treatment with ghrelin and with ghrelin plus D-Lys3-GHRP-6. A, Inhibition of growth 12, 24, 36, 48, 60 and $72 \mathrm{~h}$ after treatment with increasing concentrations of ghrelin. Data are reported as means $\pm S D(n=5)$. B, Effect of D-Lys3-GHRP-6 treatment on cell growth after ghrelin treatment. One-way ANOVA was used for statistical analysis.
siRNA. Negative control group was transfected without siRNA. After incubation for $6 \mathrm{~h}$ at $37^{\circ} \mathrm{C}$, RPMI 1640 supplemented with serum was added to wells. Cells were cultured for an additional $24 \mathrm{~h}$ at $37^{\circ} \mathrm{C}$ before analyses.

\section{Results}

\section{GHS-R expression in $\mathrm{HO}-8910$ cells}

RT-PCR was used to detect expression of GHSR mRNA in HO-8910 cells. The GHSR (348 bp) was expressed at a high level in $\mathrm{HO}-8910$ cells (Figure 1).

\section{Optimal concentrations and timing of treatment of ghrelin and D-Lys3-GHRP-6 on HO-8910 cells}

The MTT assay was used to assess the growth and viability of HO-8910 cells after treatment with varying concentrations of ghrelin, and to determine the appropriate duration of treatment to achieve the desired level of growth inhibition.

Ghrelin was added to HO-8910 media to final concentrations of 121, 152, 182, 212 and $242 \mathrm{nM}$. Numbers of viable cells were assessed at $12,24,36,48,60$ and $72 \mathrm{~h}$ (Figure 2A). The optimal concentration and duration of ghrelin treatment for $\mathrm{HO}-8910$ cells was found to be $182 \mathrm{nM}$ and $24 \mathrm{~h}$, respectively.
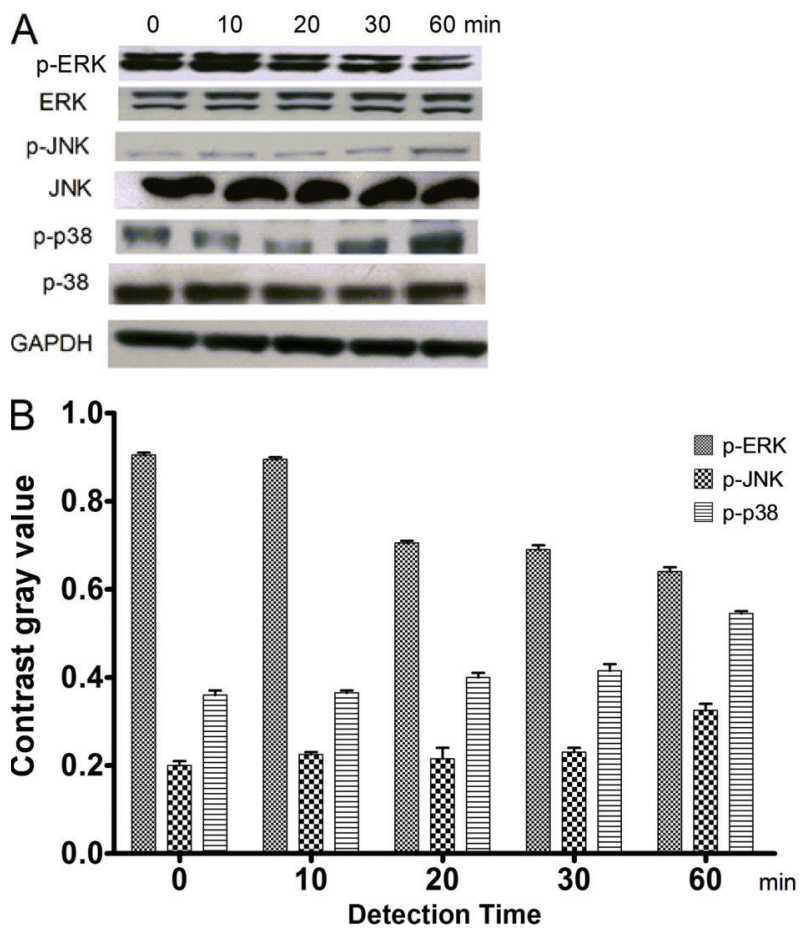

Figure 3. Effects of $182 \mathrm{nM}$ ghrelin on mitogen-activated protein kinase (MAPK) activation in HO-8910 cells. A, Expression of total and phosphorylated ERK1/2, JNKs, and p38 proteins. $B$, Contrast gray value of the phosphorylation of ERK1/2, JNKs and p38 based on Western blotting. 
Next, we determined the D-Lys3-GHRP-6 concentration needed to prevent the growth inhibition caused by $182 \mathrm{nM}$ ghrelin in HO-8910 cells. HO-8910 cells that had been treated with $182 \mathrm{nM}$ ghrelin were treated with D-Lys3-GHRP-6 $\left(10^{-5}, 10^{-6}, 10^{-7}, 10^{-8} \mathrm{ng} / \mathrm{mL}\right)$ and cell numbers evaluated at $24 \mathrm{~h}$ (Figure 2B). We found that $10^{-6} \mathrm{ng} / \mathrm{mL}$ D-Lys3-GHRP-6 could inhibit the growth inhibition caused by $182 \mathrm{nM}$ ghrelin.

\section{Ghrelin inhibited the growth of HO-8910 cells via the ERK1/2 pathway}

To ascertain which pathway has a key role in ghrelinmediated inhibition of the growth of HO-8910 cells, the phosphorylation status of the MAPKs ERK1/2, JNK and p38 was detected at $0,10,20,30$ and 60 min (Figure 3) after treatment with $182 \mathrm{nM}$ ghrelin. A decrease in ERK1/2 phosphorylation was greater than that observed for JNK or p38 after $20 \mathrm{~min}$.

When this treatment was repeated with addition of $10^{-9} \mathrm{mg} / \mathrm{mL}$ D-Lys3-GHRP-6, ERK1/2 phosphorylation was reduced compared with treatment with ghrelin alone. The phosphorylation status of JNK and p38 were not changed significantly (Figure 4).
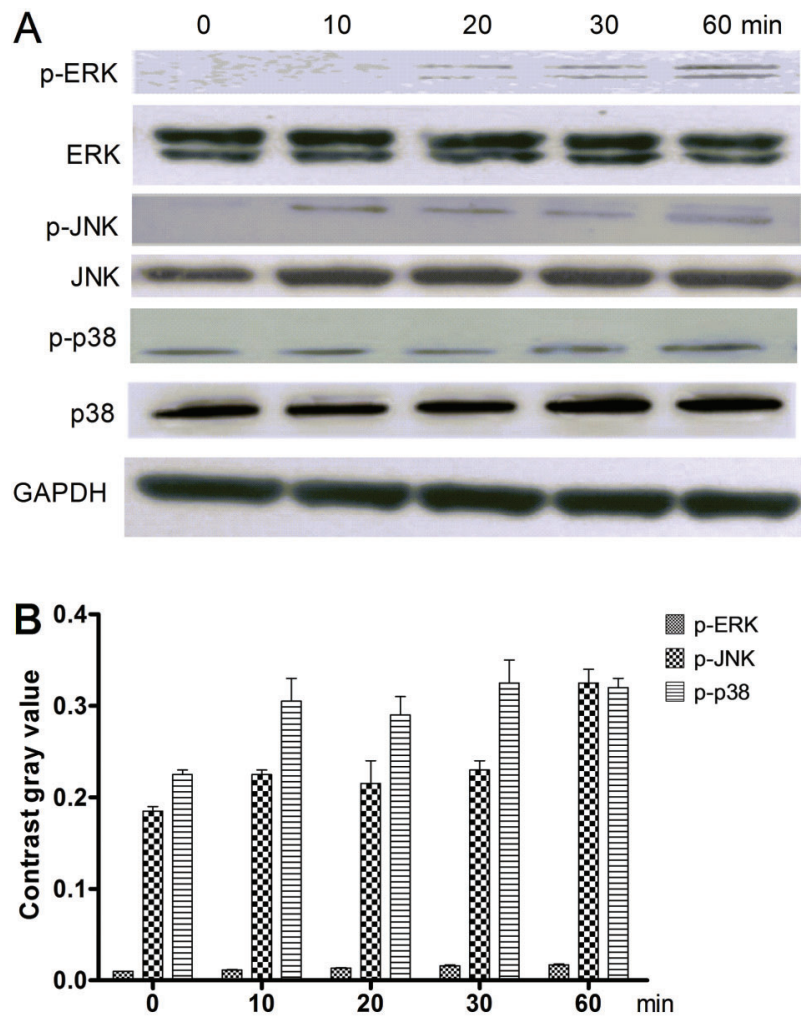

Figure 4. Effects of an inhibitor of the ghrelin receptor (D-Lys3GHRP-6) on ghrelin-mediated MAPK activation in HO-8910 cells. $A$, Expression of total and phosphorylated ERK1/2, JNKs, and p38 proteins at $0,10,20,30$ and $60 \mathrm{~min}$. $B$, Contrast gray value of the phosphorylation of ERK1/2, JNKs and p38 based on Western blotting.

\section{A Negative Control Transfection

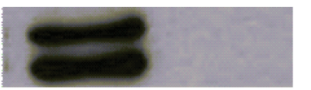

B

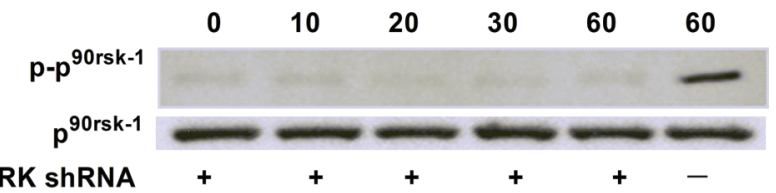

Figure 5. Effects siRNA knockdown of ERK1/2 on ERK1/2, $\mathrm{p}^{90 \text { rsk }}$ and phosphorylation of $p^{90 r s k}$. $A$, Expression of ERK1/2 after ERK1/2 knockdown. $B$, Expression of $p^{90 r s k}$ and phospho-p ${ }^{90 r s k}$ at different times after knockdown (0, 10, 20, 30, $60 \mathrm{~min})$.

This result suggested that ERK1/2 has a key role in the ability of ghrelin to block the growth of HO-8910 cells. To verify this finding, siRNA specific for ERK1/2 was used to knock down ERK1/2 expression (Figure 5). Also, the phosphorylation of $p^{90 r s k}\left(p-p^{90 r s k}\right)$ was low (Figure 5).

After reduction of ERK1/2 by siRNA knockdown, ghrelin (182 $\mathrm{nM}$ ) was no longer able to reduce the growth of $\mathrm{HO}-8910$ cells (Figure 6).

\section{Discussion}

Ghrelin is produced predominantly by the stomach, though smaller amounts are produced by the bowel, pancreas, pituitary, kidneys, and placenta. The GHSR is a typical $\mathrm{G}$ protein-coupled seven-transmembrane receptor (15). Several studies have identified the protective effects of ghrelin (4,16-18), but little is known about the effects of ghrelin on ovarian cancer cells or their mechanism of action. We found that the mechanism through which ghrelin inhibits the growth of HO-8910 cells involves the ERK1/2 branch of MAPK pathways. Maximum inhibition of the growth of HO-8910 cells was achieved using $182 \mathrm{nM}$ ghrelin for $24 \mathrm{~h}$. We also demonstrated that this effect of

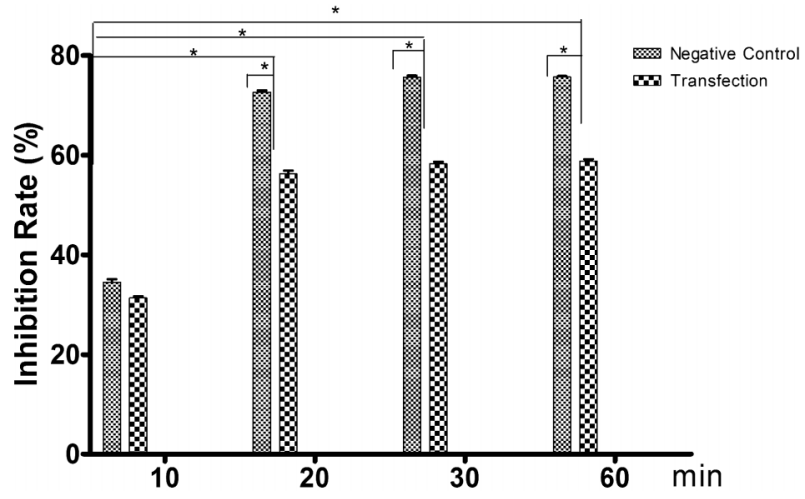

Figure 6. Prevention of ghrelin-mediated growth inhibition in HO-8910 cells after knockdown by siRNA of ERK1/2. ${ }^{*} \mathrm{P}<0.05$ (one-way ANOVA). 
ghrelin was mediated through its receptor, the GHSR (19), which were shown to be expressed at high levels in HO-8910 cells. Experiments in which the GHSR inhibitor D-Lys3-GHRP-6 $\left(10^{-6} \mathrm{ng} / \mathrm{mL}\right)$ blocked ghrelin-mediated growth inhibition provided further support for the role of the GHSR.

To gain further insight into the mechanism by which ghrelin inhibits growth of HO-8910 cells, we evaluated the activity of signaling pathways downstream of the GHSR. MAPKs are a family of serine/threonine kinases that includes ERK, JNK and p38. These kinases are involved primarily in activation of the nuclear transcription factors that control the proliferation, differentiation and apoptosis of cells (20). Our study suggests that ghrelin inhibits the growth of HO-8910 cells via the ERK signaling pathway, and not through activation of JNK or p38. We found that

\section{References}

1. Kuan AS, Teng CJ, Wu HH, Su VY, Chen YT, Chien SH, et al. Risk of ischemic stroke in patients with ovarian cancer: a nationwide population-based study. BMC Med 2014; 12: 53, doi: 10.1186/1741-7015-12-53.

2. Nurkalem C, Celik H, Dagli F, Gurates B, Kavak B, Dogan Z, et al. Ghrelin and obestatin expression in serous ovarian tumours. Gynecol Endocrinol 2012; 28: 941-944, doi: 10.3109/09513590.2011.650753.

3. Xu Y, Pang X, Dong M, Wen F, Zhang Y. Ghrelin inhibits ovarian epithelial carcinoma cell proliferation in vitro. Oncol Rep 2013; 30: 2063-2070.

4. Milewski L, Wojtowicz K, Roszkowski PI, Barcz E, Ziarkiewicz-Wroblewska B, Kaminski P, et al. Expression of ghrelin and its receptors in ovarian endometrioma. Gynecol Endocrinol 2012; 28: 310-313, doi: 10.3109/09513590.2011.631628.

5. Kojima M, Kangawa K. Ghrelin: from gene to physiological function. Results Probl Cell Differ 2010; 50: 185-205.

6. Kojima M, Kangawa K. Ghrelin: more than endogenous growth hormone secretagogue. Ann N Y Acad Sci 2010; 1200: 140-148, doi: 10.1111/j.1749-6632.2010.05516.x.

7. Kojima M, Kangawa K. Structure and function of ghrelin. Results Probl Cell Differ 2008; 46: 89-115, doi: 10.1007/400_2007_049.

8. Kojima M. The discovery of ghrelin - a personal memory. Regul Pept 2008; 145: 2-6, doi: 10.1016/j.regpep.2007.09.023.

9. Anderson LL, Jeftinija S, Scanes CG, Stromer MH, Lee JS, Jeftinija $\mathrm{K}$, et al. Physiology of ghrelin and related peptides. Domest Anim Endocrinol 2005; 29: 111-144, doi: 10.1016/j. domaniend.2005.02.033.

10. Camina JP. Cell biology of the ghrelin receptor. $J$ Neuroendocrinol 2006; 18: 65-76, doi: 10.1111/j.1365-2826.2005.01379.x.

11. Yeh AH, Jeffery PL, Duncan RP, Herington AC, Chopin LK. Ghrelin and a novel preproghrelin isoform are highly expressed in prostate cancer and ghrelin activates mitogenactivated protein kinase in prostate cancer. Clin Cancer Res 2005; 11: 8295-8303, doi: 10.1158/1078-0432.CCR-05-0443.

12. Northrup R, Kuroda K, Duus EM, Barnes SR, Cheatham L, Wiley T, et al. Effect of ghrelin and anamorelin (ONO-7643),
20-60 min of ghrelin treatment was required to inhibit ERK phosphorylation, so stimulation was time-dependent. Furthermore, GHSR blockade by chemical inhibition and silencing of ERK by siRNA suppressed ghrelin-mediated inhibition of the growth of $\mathrm{HO}-8910$ cells.

Overall, our study suggests that the ghrelin/GHSR signaling pathway attenuates the growth of HO-8910 cells mainly through an ERK-dependent pathway. Thus, ghrelin could be a target for ovarian cancer therapy. Despite this promising finding, further study is necessary before clinical application is considered.

\section{Acknowledgments}

This work was supported by a grant from the Inner Mongolia Natural Science Foundation (\#2013MS11115).

a selective ghrelin receptor agonist, on tumor growth in a lung cancer mouse xenograft model. Support Care Cancer 2013; 21: 2409-2415, doi: 10.1007/s00520-013-1800-0.

13. Lundholm K, Gunnebo L, Korner U, Iresjo BM, Engstrom C, Hyltander A, et al. Effects by daily long term provision of ghrelin to unselected weight-losing cancer patients: a randomized double-blind study. Cancer 2010; 116: 2044-2052, doi: 10.1002/ cncr.24917.

14. Caminos JE, Gualillo O, Lago F, Otero M, Blanco M, Gallego $\mathrm{R}$, et al. The endogenous growth hormone secretagogue (ghrelin) is synthesized and secreted by chondrocytes. Endocrinology 2005; 146: 1285-1292, doi: http://dx.doi.org/ 10.1210/en.2004-1379.

15. Fujitsuka $\mathrm{N}$, Asakawa $\mathrm{A}$, Amitani $\mathrm{H}$, Hattori $\mathrm{T}$, Inui $\mathrm{A}$. Efficacy of ghrelin in cancer cachexia: clinical trials and a novel treatment by rikkunshito. Crit Rev Oncog 2012; 17 : 277-284, doi: 10.1615/CritRevOncog.v17.i3.50.

16. Bai R, Zhao P, Cao G, Wen S, Li Q, Meng Q. Ghrelin promotion of oocyte maturation via ERK1/2 pathway in ovis aries. Cell Mol Biol 2012; 58 (Suppl): OL1797-OL1802.

17. Hosoda H, Kangawa K. [Role of ghrelin in cancer]. Nihon Rinsho 2004; 62 (Suppl 9): 421-423.

18. Rak A, Szczepankiewicz D, Gregoraszczuk EL. Expression of ghrelin receptor, GHSR-1a, and its functional role in the porcine ovarian follicles. Growth Horm IGF Res 2009; 19: 68-76, doi: 10.1016/j.ghir.2008.08.006.

19. Kamegai J, Wakabayashi I, Miyamoto K, Unterman TG, Kineman RD, Frohman LA. Growth hormone-dependent regulation of pituitary $\mathrm{GH}$ secretagogue receptor (GHS-R) mRNA levels in the spontaneous dwarf Rat. Neuroendocrinology 1998; 68: 312-318, doi: 10.1159/000054379.

20. Delhanty PJ, van der Eerden BC, van der Velde M, Gauna C, Pols HA, Jahr $\mathrm{H}$, et al. Ghrelin and unacylated ghrelin stimulate human osteoblast growth via mitogen-activated protein kinase (MAPK)/phosphoinositide 3-kinase (PI3K) pathways in the absence of GHS-R1a. J Endocrinol 2006; 188: 37-47, doi: 10.1677/joe.1.06404. 